\title{
Imperatives of Effective Working Capital Management and Profitability in the Banking Industry in Nigeria
}

\author{
Casmir C. Osuji ${ }^{1} \&$ Andrew O. Agbada ${ }^{1}$ \\ ${ }^{1}$ Faculty of Management Sciences, Accounting, Banking and Finance Department, Delta State University (DELSU), \\ Asaba Campus, Delta State, Nigeria \\ Correspondence: Andrew O. Agbada, Faculty of Management Sciences, Accounting, Banking and Finance \\ Department, Delta State University (DELSU), Asaba Campus, Delta State, Nigeria.
}

Received: November 4, 2019

Accepted: December 16, 2019

Online Published: March 17, 2020

doi:10.5430/ijfr.v11n2p229

URL: https://doi.org/10.5430/ijfr.v11n2p229

\begin{abstract}
This study explored the imperatives of effective Working Capital Management (WCM) and Profitability in the banking industry in Nigeria. WCM core variables namely: Short-term Investments; Credits to customers and Account Receivables and Payables were used as proxy. Survey design was adopted and data were collected using questionnaires and analyzed with Pearson Product-Moment Correlation Coefficient (PPMCC) denoted by ' $r$ '. The findings to an extent counter apriori expectation. Though the values of ' $r$ ' exhibited positive signs affirming positive relationship, the strength of relationship is on the average. This was affirmed by the values of $\left(\mathrm{r}^{2}\right)$, especially that of the variable "Credits to customers' which stood low at 0.2229 , meaning that the variable explained only $22.29 \%$ variation in Profitability. By implications, the results suggest that WCM variables have not yielded sufficient cash flows that could optimize profits. We therefore recommend efficient surveillance of WCM variables in order to reduce instances that lead to funds losses.
\end{abstract}

Keywords: account receivables \& payables, credits to customers, short-term investments, working capital management (WCM), profitability, banking, Nigeria

JEL classification: C54; G00; G21; G39.

\section{Introduction}

The concepts of Working capital management (WCM) and Profitability cut across industries in every nation's economy. These concepts are commonly encountered in firms' operations and they draw the attention of industry managers desiring to remain concurrently liquid and profitably viable. Indeed, Working Capital Management (WCM) is of great importance in the banking sector. Banks rely on it to balance the desires to make profit and to remain liquid. It entails managing resources effectively in such a manner to meet the needs of liquidity and profitability in a somewhat equilibrium state - being able to remain liquid and make substantial profit concurrently. This is core for banking business to thrive. At this point it may be necessary to define Working capital and succinctly discuss some reasons why Working Capital Management is crucial to the operational processes of firms. Wikipedia encyclopedia averred that Working capital (WC) is a financial measure representing the amount of operating liquidity available to a business entity, including governmental entities. Working capital deficiency is a symptom of distress for any business. In particular, it has the ability to trigger off bank failure and liquidation. This is because Working capital is utilized in running the day-to-day activities in banking firms. The amount of capital available amongst other variables is a measure of the degree of soundness of a bank. Thus, the liquidity of a bank is determined by the availability of sufficient Working capital. The capital may be cash, short term assets that is transferable and investment in securities such as treasury bills that are realizable easily at short notice without posing or constituting difficulties to the bank. These assets and securities enable banks acquire funds promptly to meet payment obligations and financial commitments. In the banking industry, working capital components is made up mostly of cash holdings or near cash assets. However, large sums of working capital holding may not earn the bank reasonable income particularly when held as idle cash and this brings to fore the reason for its management.

Working Capital Management (WCM) is crucial to the operations of firms generally and in particular to banking operations. Effective and efficient coordination of the variables of WCM is an important aspect of financial management. Adogoke (2017) observed that some banking firms in Nigeria that were seen to have been able to 
acquire some promising investments and yielding high rate of returns have turned out to be failures and have been frustrated into liquidation due to lack of or inadequacy of working capital resulting from incompetence in Working Capital Management. The prevailing liquidity problem in the industry is mounting pressures on cash and credits and seriously affecting the survival of several banking firms. Consequently, several banks in the industry, irrespective of their age in operations, capital base and size have been experiencing herculean difficulties trying to meet with short term maturing obligations and liabilities. This is because they are not able to meet the level of the demands on their working capital effectively and efficiently. The management teams of these ailing banks are constantly being confronted with formidable array of problems and challenges in striving to meet with their level of working capital requirement and remain afloat. Deductions from empirical and theoretical literatures have revealed that the liquidity problems revolve mostly around the following: inadequate cash reserves, improper coordination of funds, improper management of WCM variables, non-adherence to rules and regulations in approving loans to customers, non-monitoring of loans repayment extended to loan customers, incessant withdrawals by customers due to lack of confidence as a result of distressing syndromes often being exhibited by banking firms in the industry.

In businesses generally, Working capital management directly affects the profitability and liquidity of firms despite their sizes. Researchers have tackled Working capital management issues in a number of ways. There appear to be a consensus that Working capital management impacts on returns or profitability and on the firm's value (Deloof, 2013). Thus, efficient Working capital management is known to have many favourable effects on the firms' overall performance. It helps firms to efficiently allocate scare resources and funds in payment of short term commitments and claims (Peel \& Wilson 2016), It enhances owner's net-worth and facilitates productivity by way of effective coordination of scarce resources to make good profits and putting back profits into the business thus reducing the possibility of failure or liquidation particularly amongst small businesses (Berryman, 2017). From this perspective, as liquidity of a banking firm must be ensured, it becomes imperative to effectively manage Working capital to make reasonable level of profits. According to Wingaroja and O'Neil, (2018), efficient Working capital management ensures the provision of liquidity for all-round economic activities and attainment of profit generating processes in the firm. It facilitates or helps to allocate funds to all the components or departments of the firm thereby, ensuring efficient mix of the firm's operations and that gives it the sense of operating with or without adequate capital (Osisioma, 2017).

It is of necessity to know and understand the relationship between effective Working capital management and Profitability - the profit making ability or the degree to which a banking business yields profit that culminates into performance. If a bank is deficient in cash holdings to meet withdrawal obligations and pay for its current or running expenses, it may become bankrupt or liquidate out rightly being unable to pay off debts. On the other hand, too much cash holding is harmful to profit making. When it invests excessively or holds too many investments in assets at the detriment of adequate cash, it amounts to poor use of funds and resources. It is from these viewpoints that this study is focused on exploring the core areas of Working Capital management whose cash flows are of significant importance to profit making and liquidity needs of banks. According to Maverick (2019), effective Working Capital management requires coordinating several tasks but the core and fundamental areas include:

i. Managing Short-term Investments;

ii. Managing Credits to customers and

iii. Managing Account Receivables and Payables.

Account Receivables and Payables are regarded as crucial elements of Working capital management because they are the amounts or revenue owed to the bank and claims that must be paid out to suppliers, et cetera by the bank respectively. While Receivables are current assets, Payables are current liabilities and the difference is a proportion of working capital. The effective management of these three crucial areas of WCM mentioned above ensures that a bank maintains enough cash flow to meet its short-term operating costs, liquidity and profit needs. Therefore, for the purpose of this study, we use these crucial areas as the independent variables to explain Profitability in the banking industry in Nigeria. Although several studies may have been carried out in this field of study, this study is specifically focused on the imperative of effective Working Capital Management and Profitability in the banking industry in Nigeria and analyzed using Pearson Product-moment Correlation Coefficient with the hope of filling an existing gap in this area of finance. Although data employed are sourced from Nigeria, inferences deduced are of general application in the business world. 


\subsection{Statement of the Problem}

Inefficient Working Capital management is a vice, a kind of weakness or frailty in any firm, especially banking firms' management processes universally. As a matter of fact, evidences of distresses and liquidations abound if a firm inefficiently carry out its Working capital management. Distresses in banks have become a major and conspicuous problem having serious negative bearing on the liquidity state of most banking firms in Nigeria in the last three decades. The negative consequences of this has been heavy on the profit making ability of affected firms and ultimately on the general performance of the banking industry (Oluboyede, 2017). The current pressure on cash and credits is affecting the survival of many banks in Nigeria. Many banks irrespective of their size have been experiencing difficulties meeting short term maturing obligations and liabilities. The consequences have been obvious as per the dwindling performance in the industry. The problems have revolved around inadequate cash holdings emanating from improper cash flows, the banks being unable to manage properly Short-term Investments, and Account Receivables and Payables, especially Credits to customers are fast becoming toxic assets in the industry.

Thus, the illiquidity state of most banking firms in Nigeria believed to have emanated from poor Working capital management provided strong motivation for carrying out this study titled:- Imperative of effective Working Capital management and Profitability in the banking industry in Nigeria.

\subsection{Objectives of the Study}

To state appropriately the objectives of this study, Working Capital management is broken into its components, the fundamental areas adopted for the purpose of this study. We reiterate them as: Managing Short-term Investments; Managing Credits to customers and Managing Account Receivable and Payables. From the foregoing, the core objective of this study is to determine the relationship between effective management of Short-term Investments, Credits to customers, Account Receivable/Payable and Profitability in the banking industry in Nigeria.

\subsection{Statement of Hypotheses}

Based on the objective above, we state the following null hypotheses to enable us test, deduce inferences and make logical conclusions on the study:

H01: There is no relationship between effective management of Short-term Investments and Profitability in the banking industry in Nigeria

H02: There is no relationship between effective management of Credits to customers and Profitability in the banking industry in Nigeria.

H03: There is no relationship between effective management of Account Receivable and Payable and Profitability in the banking industry in Nigeria.

\section{Review of Related Literatures}

Globally, one of the important goals of Working capital management generally is to ensure that firms and banks in particular have enough, regular and consistent cash flow for operational activities and essentially, to make profits. This objective is particularly heightened for financial institutions and banks in particular with respect to profit making. Thus, Working capital management is a crucial aspect of banking and it constitutes a pivotal and distinct element of overall financial management. The liquidity preference theory in some ways could serve as an underlying theory for Working capital management. The Liquidity Preference theory is simply the demand for money considered as liquidity. According to Chen (2019), Liquidity preference theory suggests that an investor demands a higher interest rate or premium on securities with long-term maturities that carry greater risk because all other factors being equal, investors prefer cash or other highly liquid holdings. According to the theory, money or cash is the utmost liquid asset. Liquidity is thus seen as an asset, a current asset. An asset is said to be liquid when it can be easily converted into cash and when it does, it provides liquidity for the firm to run its day-to-day operational costs, it enables the firm to pay its short term obligations and it is used as well to invest in other working capital components. Thus, when there is a decrease in the liquidity level of a firm, it may result to a negative net working capital which may well lead to insolvency.

An appreciable level of Working capital is needed for operations in the banking industry to meet the day-to-day running expenses that are ever increasing owing to inflation and to make sufficient profits. Be that as it may, in banking businesses, being simultaneously profitable and liquid is not negotiable at least for two reasons. It is required that bank should meet regular cash flow requirements to sustain profits and to guarantee enough liquidity for customers' unannounced withdrawals. Withdrawals are vital, urgently needed and absolutely necessary obligations banks owe to their clients' financial instruments that are unconditional orders. In this sense, Working capital management is a 
managerial duty involving the continuous monitoring of the optimal position of the bank's cash flows in order to meet short-term operating costs and short-term debt obligations and to strike a balance between liquidity and profitability during the daily operations of the business (Rahaman and Nasr, 2017). Umoren and Udo (2015) looked at the effects of Working capital management on the profitability and liquidity of some Deposit Money Banks using descriptive statistics, regression and Pearson's correlation coefficients parameters. The study revealed that there is a significant negative relationship between profitability and cash conversion cycle. Ogodor and Mukolu (2015) worked on Working capital adequacy and organization performance. They chose First Bank Nigeria Plc and Guaranty Trust Bank Plc for their analysis using Ordinary Least Square (OLS) as its estimation technique and the result of their findings revealed that Working Capital management did have a significant impact on bank performance during the period under review. Mandiefe (2016) examined the effect of working capital management on the profitability of Afriland First Bank of Cameroon using a twelve-year time series data (2002-2013), which was extracted from the bank's financial statement. The result of the analysis showed that Working capital management had positive impact on Afriland First Bank of Cameroon profitability.

Usually, working capital serves similar purposes is all industries, notably to meet daily running expenses. We therefore evaluate few researches on non-banking firms as examples. Lovey (2016) carried out a study to find out the effect of Working Capital management on a company's profitability. Using the Pearson's correlation coefficients of the Ordinary least square regression analysis, the following findings were revealed; that there exists a positive relationship between the cash conversion cycle and profitability of a firm. This means that as the cash conversion cycle increases, company profitability increases. However, there was a negative relationship between liquidity and profitability showing that as liquidity decreases, profitability increases. Ahmed (2015) examined the effect of Working Capital management on profitability of selected manufacturing companies in Nigeria. Using panel data, least square method of regression, the study found a significant relationship between working capital and profitability. The conclusion of the study was that Working capital management has significant impact on profitability of manufacturing companies and recommends that companies should manage their cash, receivables, inventories and payables with a view of reducing the cash conversion cycle so as to increase their profitability. In their research study Hoque Mai and Anwor (2015), examined working capital management and profitability in a cement industry in Bangladesh and discovered that working capital position over the period under study do not satisfactorily impact on the company profits. Bandara (2015) also look at the impact of working capital management policy on market value addition in Sri Lankan companies. Descriptive statistics, correlation and regression parameters adopted as the tools for analysis revealed positive relationship.

In this study, we adopted Maverick (2019), definition above which says that 'effective Working Capital management requires coordinating several tasks but the fundamental areas include: Managing Short-term Investments; Managing Credits to customers and Managing Account Receivable and Payables as our working definition. Short-term Investments are major component of Working capital because they constitute a proportion of current assets. Firms and banks in particular undertake Short-term Investments such as Treasury bills as liquidity buffer that can easily be converted to cash should there be sudden large cash demand. According to Samiloglu and Demirgunnes, (2008), liquidity as a function of current assets and current liabilities, is an important factor in determining working capital policies and indicates firm's capability of generating cash in case of need. So the efficient management of Short-term Investments ensures that banks have sufficient cash flow at all times to meet short-term debt obligations and operating expenses. Credits to customers also constitute a major component of Working Capital Management. Sayers, (1970), opined that banks seek to make themselves as attractive as debtors and as efficient as creditors that they can earn a substantial gross income from the difference between the interest they charge as creditors and the interest they pay as debtors'. In this study, the third core component of Working Capital Management is Account Receivables and Payables. Let's reiterate that while Receivables are current assets, money the bank owns that must be collected from debtor; Payables are current liabilities, amount the bank owed to clients. The difference between the current assets and current liabilities is referred to as Working capital. Sabo (2015) examined the impact of Working capital management on corporate profitability. Using the regression analysis, the results showed that there is a positive relationship between average collection period and profitability. Average collection period as used here indicates that the study was focused on Account Receivables and Payables and it was a positive relationship with Profitability. Conclusively, effective Working capital management strategy is aimed at maintaining efficient levels of both the current assets and current liabilities in order to achieve cash sufficient enough to meet short term obligations and operating expenses. Failure to raise enough funds to meet debt and withdrawal obligations could result to panic drawings that have the ability to create a run on the banking system and ultimately liquidation of firms. It is against this backdrop that the study seeks to explore the imperative of effective Working Capital Management and Profitability in the banking industry in Nigeria. 


\section{Research Methodology}

Research Methodology contains the specific systems and techniques utilized for collecting and analyzing data and for evaluating the validity and reliability of outcomes. This section is sub-divided into three sub-sections namely: Research design and Sampling technique, Population and Sample size, Analysis technique and Model specification.

\subsection{Research Design and Sampling Techniques}

Survey Research Design was adopted in sourcing for data in this study with the aim of obtaining maximum insight from the survey carried out. The Random sampling technique in which each item in the sample population was chosen strictly by chance with each item having equal chance of being chosen was employed in the survey. Generally, the random sampling technique is considered an appropriate method for obtaining a fair survey of the study population. The sampling instrument used is structured questionnaire. The questionnaire took the 'Item-Specific-Response-Options (ISRO)' strategy in which a set of response options are aligned to a specific question. Usually, ISRO strategy uses five-point rating scale like the Likert scale but the ISRO strategy is considered a better option to the Likert scale strategy believed to be full of biases that prevent objective consideration of the situation under review. The answer options in the ISRO scale for example range from: Very Affirmative; Somewhat Affirmative; Neither Affirmative nor Negative; Somewhat Negative and Very Negative and are weighted 5, 4, 3, 2 and 1 respectively.

\subsection{Population and Sample Size}

In research studies generally, Population is the totality of objects or individuals having the same traits or characteristics that are under focus. In this study the population size covers all employees of Banking Service Providers (BSPs) in Nigeria who are in the lower, middle and top management levels. The collection of data was carried out using Population Sampling technique. This involves the study of a subset of representative of the entire population in order to draw up logical conclusion of general application to the research population. So, the Sample size of the study consists of 500 employees of Banking Service Providers (BSPs) in Nigeria who are in the lower, middle and top management levels and drawn from metropolitan cities of Lagos, Benin City, Abuja, Ibadan, Port Harcourt and Warri. The Sample size of 500 employees is considered sufficiently large enough to justify statistical analysis.

\subsection{Data Analysis Technique and Model Specification}

The analysis of data obtained from field survey was carried out using Pearson's Product-Moment Correlation Co-efficient (PPMCC) denoted by the letter ' $r$ '. PPMCC or ' $r$ ' is a statistical tool notably utilized for computing correlation coefficient between variables that have linear relationship. It indicates the direction of relationship because it shows whether the relationship is positive or negative. It also indicates the degree of linear relationship between the variables which is either expressed in numerical decimal or in a percentage. In this study, PPMCC ' $r$ ' is considered very suitable to determine the relationship between Working capital management and Profitability as it would allow us make inferences of general application to firms in various industries and operating in various nations. The weighted answer options were employed in computing the value of ' $\mathrm{r}$ '. According to Oaikhenan and Udegbunam (2004), for two linearly related variables X and Y, the PPMCC or ' $r$ ' is computed using the formula expressed in equation 1 :

$$
r=\frac{\sum(X-\bar{X})(Y-\bar{Y})}{\sqrt{\sum(X-\bar{X})^{2} \sum(Y-\bar{Y})^{2}}}
$$

Where: $r=$ Pearson's Product-Moment Correlation Coefficient (PPMCC)

$\mathrm{X}=$ Weighted response options

$\mathrm{Y}=$ Frequency of response options

$\sum=$ Summation sign

$\bar{X}=$ Mean of weighted response options

$\bar{Y}=$ Mean of frequency of response options

Mathematically, the expression in equation 1 above is rather complex and fairly difficult to calculate numerically. For this reason, a simpler equation is provided by Oaikhenan and Udegbunam (2004), for calculating ' $r$ ' as expressed in equation 2 . Thus, in this study, ' $r$ ' is computed with: 


$$
r=\frac{\sum x y}{\sqrt{\sum x^{2} \sum y^{2}}}
$$

Where

$\mathrm{x}=X-\bar{X}$ and

$\mathrm{y}=Y-\bar{Y}$

\subsection{Decision Rule for the Estimated Model}

As per direction, the value of PPMCC or ' $r$ ' lies between -1 to 1 (i, e., $-1 \leq r \leq 1$ ).

If the value of ' $r$ ' is zero (that is, $r=0$ ) then, no relationship exists between the variables under review.

If the value of ' $r$ ' is 1 , it portends a perfect linear relationship. As the value of ' $r$ ' decreases towards 0 , the weaker is the linear relationship and when it is less than 1 , it shows a negative relationship.

If the value of $r$ is squared, it gives the Coefficient of Determination (r2), the parameter that indicates the goodness of fit of the model under estimation.

\section{Data Presentation and Analysis of Results}

\subsection{Presentation of Data}

Three null hypotheses were formulated in section 1 to be tested. This will be done using the data obtained from field survey now presented first in a tabular form and also in Pie chart for clarity. Earlier, we stated that five hundred (500) structured questionnaires in conformity with Item-Specific Response Options (ISRO) strategy were distributed. The distribution of questionnaires was rigorously carried out in a random manner to achieve the goal of the study. However, four hundred and fifty two copies (452), constituting $90.40 \%$ were retrieved and used for the computation of PPMCC or ' $r$ '.

\subsubsection{Presentation of Data for Hypothesis 1}

Specific questions conforming to our stated hypotheses were asked with the intention of using their response frequencies and weights allotted to response options to test the hypotheses. Question two (2) in the questionnaire relates to the Management of Short-term Investments and Profitability in the banking industry in Nigeria. This question is considered suitable to test hypothesis 1 (H01). Question two (2) states thus:

'How contented or discontented would you say that the management of Short-term Investments is effective and could enhance Profitability in the banking industry in Nigeria?'

Response frequencies and their percentages are displayed in Table 1. From the table, the percentage of respondents who are very contented that the management of Short-term Investments is effective and could enhance Profitability in the banking industry in Nigeria stood at $22.79 \%$; those that are somewhat contented stood at $49.78 \%$ and together they both sum up to be $72.57 \%$.

Table 1. Responses to short-term investments and profitability

\begin{tabular}{lll}
\hline Response Options & Response Frequencies & Frequencies in Percentages (\%) \\
\hline Very Contented & 103 & $22.79 \%$ \\
\hline Somewhat Contented & 225 & $49.78 \%$ \\
\hline Neither Contented nor Discontented & 57 & $12.61 \%$ \\
\hline Somewhat Discontented & 31 & $6.86 \%$ \\
\hline Very Discontented & 36 & $7.96 \%$ \\
\hline Total & 452 & $100 \%$ \\
\hline
\end{tabular}

Source: Field Survey, 2019 
In terms of percentage of response, the results appear to suggest that Short-term Investments are fairly well managed to positively affect Profitability. However, it seems that more efforts must be required to improve profitability as the figure indicates. It is hoped that more facts about this variable will be revealed when analyzed with Pearson Product-moment Correlation Coefficient. Below is the Pie-chart in Figure 1 computed to clearly demarcate the magnitude of the response options frequencies indicated in percentages.

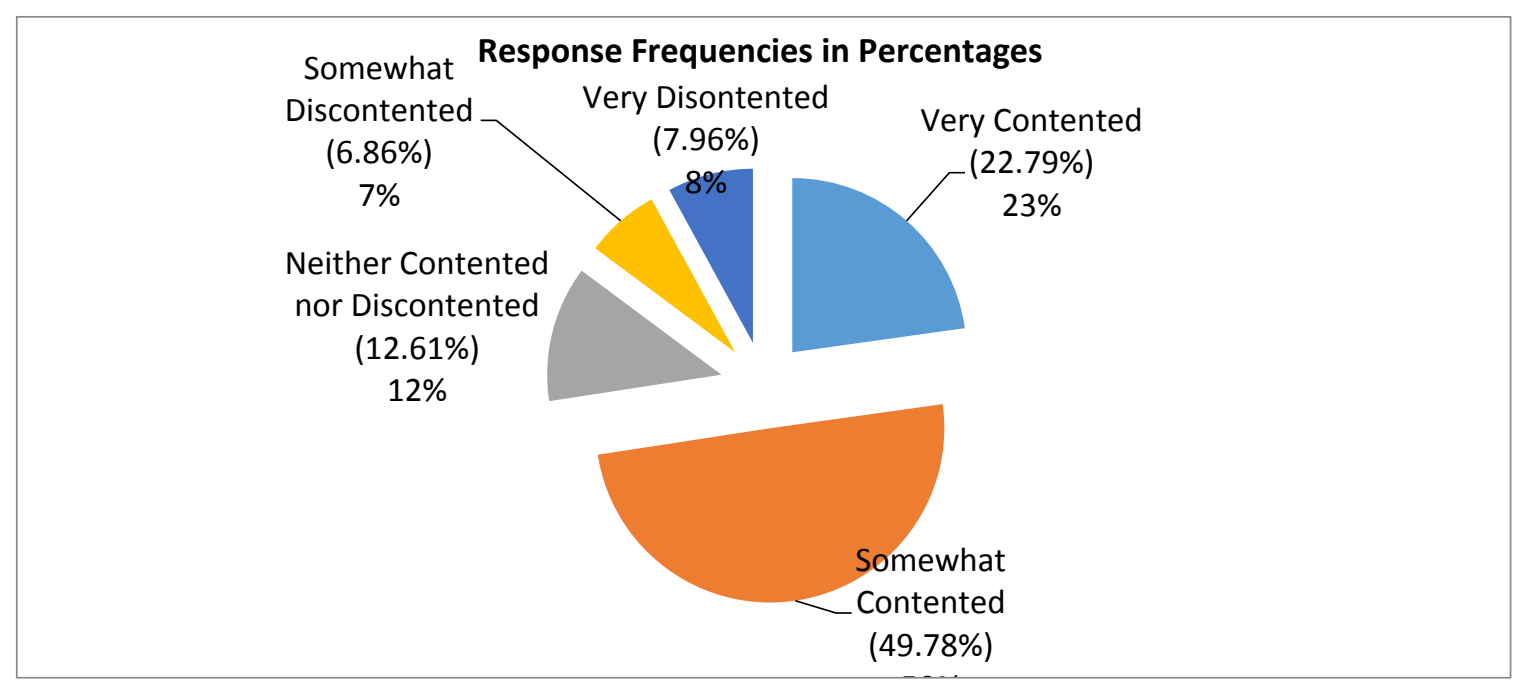

Figure 1. Responses to short-term investments and profitability

Source: Authors' computation using Field Survey data, 2019.

\subsubsection{Presentation of Data for Hypothesis 2}

Question four (4) relates to the Management of Credits to customers and Profitability in the banking industry in Nigeria. This question is also considered suitable to test hypothesis 2 (H02). Question four (4) is stated as follows:

'How satisfied or dissatisfied would you say that the management of Credits to customers is effective and could enhance Profitability in the banking industry in Nigeria?'

Response frequencies to question 4 in figures and percentages are displayed in Table 2 . The response frequencies in the results obtained indicates that while $13.94 \%$ of respondents are very satisfied that the management of Credits to customers is effective and could enhance Profitability in the banking industry in Nigeria, $44.47 \%$ are somewhat satisfied; these figures put together constitute a total of $58.41 \%$ of respondents that are positive to the question.

Table 2. Responses to credits to customers and profitability

\begin{tabular}{lll}
\hline Response Options & Response Frequencies & Frequencies in Percentages (\%) \\
\hline Very satisfied & 63 & $13.94 \%$ \\
\hline Somewhat Satisfied & 201 & $44.47 \%$ \\
\hline Neither Satisfied nor Dissatisfied & 112 & $24.78 \%$ \\
\hline Somewhat Dissatisfied & 31 & $6.86 \%$ \\
\hline Very Dissatisfied & 45 & $9.95 \%$ \\
\hline Total & 452 & $100 \%$ \\
\hline
\end{tabular}

Source: Field Survey, 2019.

What appears obvious is that the $58.41 \%$ obtained for positive responses is suggesting that the results are on the average or relatively lower than expected. Thus, the result counters apriori expectation especially for the 'very satisfied 
option' group standing approximately at $14 \%$. This assertion is reached considering the fact that Credits constitutes the major revenue earning assets of banks. By implication, the results appear to suggest that Credits to customers may not have been maximized to contribute much to Profitability in the banking industry in Nigeria. This revelation may be part of the reason that has hindered good profit making potentials of firms in the banking industry. In Figure 2, the response frequencies expressed in percentages is replicated in a Pie-chart for clarity and distinction in the magnitudes of responses for each answer options.

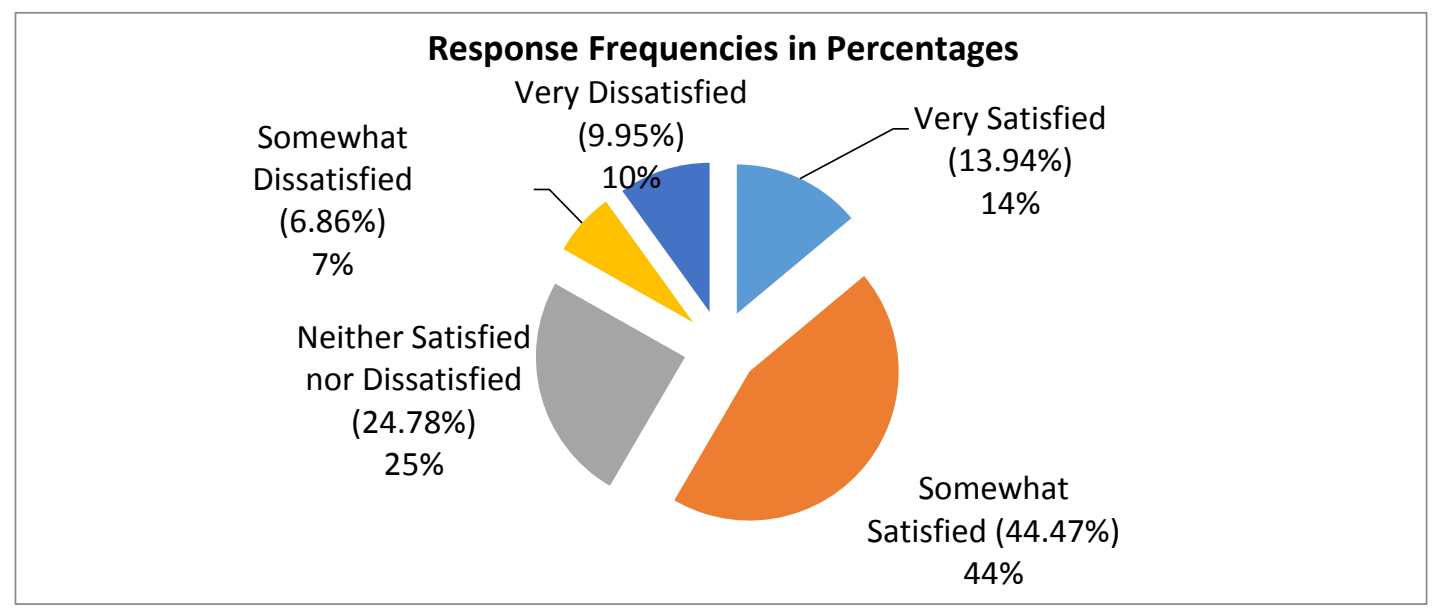

Figure 2. Responses to credits to customer and profitability

Source: Authors' computation using Field Survey data, 2019.

\subsubsection{Presentation of Data for Hypothesis 3}

In hypothesis 3, we considered the relationship that exists between Account Receivables and Payables and Profitability in the banking industry in Nigeria. Question 6 in the questionnaire was structured to conform to the hypothesis. Thus, 'Responses frequencies' to question 6 were considered suitable to test hypothesis 3 (H03). Question six (6) is stated hereunder:

'How satisfied or dissatisfied would you say that the management of Account Receivables and Payables is effective and could enhance Profitability in the banking industry in Nigeria?'

The 'Response frequencies' to question 6 in figures and also expressed in percentages are displayed in Table 3 . Interestingly, the response frequency rates to this question have some special characteristics that differ slightly from others results. It showcased higher figures for respondents who are very satisfied $(25.89 \%)$ and those somewhat satisfied (53.54\%), together, they both stood at $79.43 \%$. The affirmative figure of $79.43 \%$ is high enough to compel a conclusion that the null hypotheses should be rejected. By implication, it suggests that more attention may have been given to the management of Account Receivables and Payables and so, it may have enhanced Profitability very positively in the banking industry in Nigeria.

Table 3. Responses to account receivables \& payables and profitability

\begin{tabular}{lll}
\hline Response Options & Response Frequencies & Frequencies in Percentages (\%) \\
\hline Very satisfied & 117 & $25.89 \%$ \\
\hline Somewhat Satisfied & 242 & $53.54 \%$ \\
\hline Neither Satisfied nor Dissatisfied & 40 & $8.85 \%$ \\
\hline Somewhat Dissatisfied & 28 & $6.19 \%$ \\
\hline Very Dissatisfied & 25 & $5.53 \%$ \\
\hline Total & 452 & $100 \%$ \\
\hline
\end{tabular}

Source: Field Survey, 2019. 
However, more about this variable will be revealed on analysis using Pearson Product-moment Correlation Coefficient. The response frequencies to question 6 expressed in percentages are hereunder computed in a Pie chart for clarity of purpose as displayed in Figure 3.

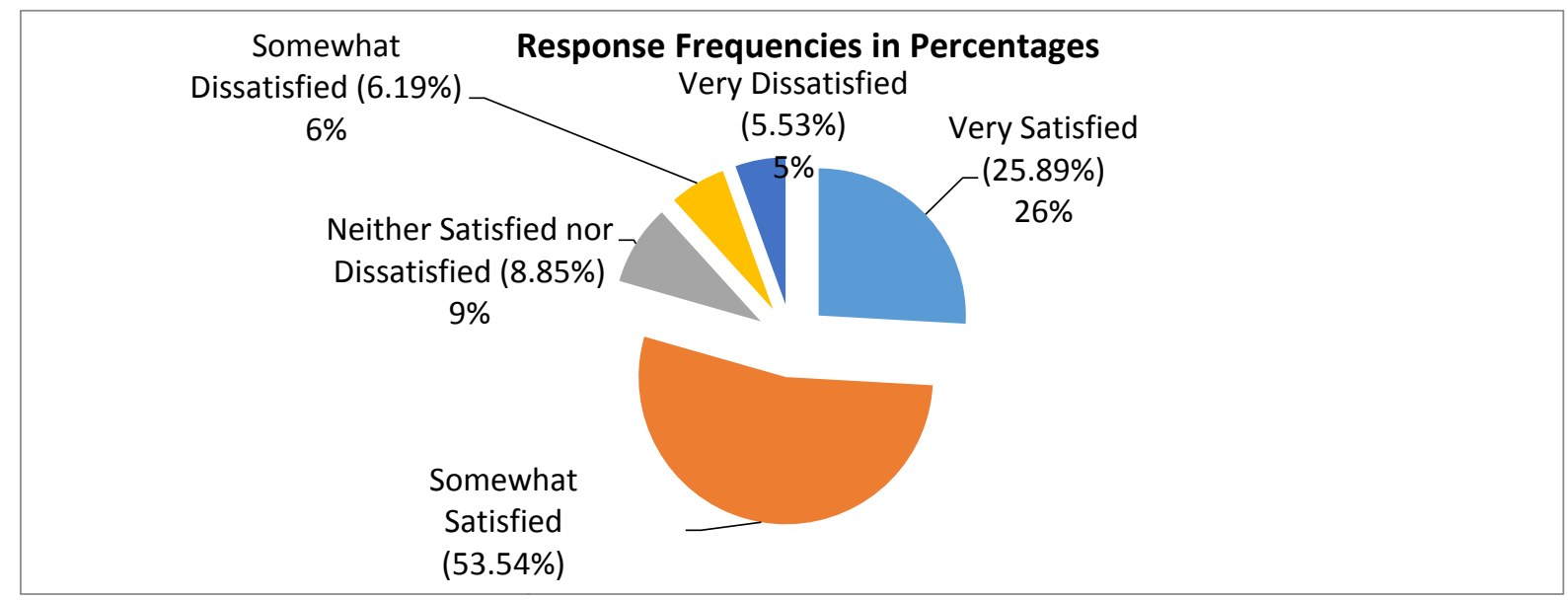

Figure 3. Responses to account receivables \& payables and profitability

Source: Authors' computation using Field Survey data, 2019

\subsection{Data Analysis and Hypotheses Testing}

In this section, the Pearson Product-Moment Correlation Coefficient (PPMCC) or ' $r$ ' for the three hypotheses formulated is computed using the specified model and analyzed.

4.2.1 Testing Hypothesis 1 (H01)

In the model specification, we indicated that Pearson Product-Moment Correlation Coefficient (PPMCC) or ' $r$ ' is

given as $r=\frac{\sum x y}{\sqrt{\sum x^{2} \sum y^{2}}}$

This model can best be manipulated through a table to arrive at the summation of products of the variables under consideration. From Table 4 above, we derived products for the computation of Pearson's Product-Moment Correlation Co-efficient (PPMCC) denominated by ' $r$ ' to enable us test and analyze hypothesis 1 which states as follows:

H01: There is no relationship between effective management of Short-term Investments and Profitability in the banking industry in Nigeria.

Table 4. Computation of PPMCC, ' $r$ ' for Short-term Investments and Profitability

\begin{tabular}{llllllll}
\hline & $\mathbf{X}$ & $\mathbf{Y}$ & $\mathbf{x}=\mathbf{X}-\ddot{\mathbf{X}}$ & $\mathbf{y}=\mathbf{Y}-\overline{\mathbf{Y}}$ & $\mathbf{x y}$ & $\mathbf{x}^{\mathbf{2}}$ & $\mathbf{y}^{\mathbf{2}}$ \\
\hline Very Contented & 5 & 103 & 2 & 12.60 & 25.20 & 4 & 635.04 \\
\hline Somewhat Contented & 4 & 225 & 1 & 134.60 & 134.60 & 1 & $18,117.16$ \\
\hline Neither contented nor Discontented & 3 & 57 & 00 & -33.40 & 00 & 00 & $1,115.56$ \\
\hline Somewhat Discontented & 2 & 31 & -1 & -59.40 & 59.40 & 1 & $3,528.36$ \\
\hline Very Discontented & 1 & 36 & -2 & -54.40 & 108.80 & 4 & $2,959.36$ \\
\hline Total $\left(\sum\right)$ & 15 & 452 & 00 & 00 & 328 & 10 & $26,355.48$ \\
\hline
\end{tabular}

Source: Authors' computation, 2019. 
The Pearson's Product-Moment Correlation Co-efficient (PPMCC), ' $r$ ' is computed thus:

Mean of Weighted Answer Options $\bar{X}=\frac{\sum X}{n}=\frac{15}{5}=3$

Mean of Frequency Response Options $\bar{Y}=\frac{\sum Y}{n}=\frac{452}{5}=90.40$

From equation 2; PPMCC $r=\frac{\sum x y}{\sqrt{\sum x^{2} \sum y^{2}}}=\frac{328}{\sqrt{10 x 26355.48}}=\frac{328}{513.38}=0.6389$

Therefore:

The Pearson's Product-Moment Correlation Co-efficient (PPMCC) or ' $r$ ' $=0.6389$

The Coefficient of Determination $(\mathrm{r} 2)=(0.6389) 2=0.4081$ or $40.81 \%$.

4.2.2 Testing Hypothesis 2 (H02)

Table 5 above, is used to derive products for the computation of Pearson's Product-Moment Correlation Co-efficient (PPMCC) ' $r$ ' to enable us analyze hypothesis 2.

Table 5. Computation of PPMCC, ' $r$ ' credits to customers and profitability

\begin{tabular}{llllllll}
\hline & $\mathbf{X}$ & $\mathbf{Y}$ & $\mathbf{X}=\mathbf{X}-\ddot{\mathbf{X}}$ & $\mathbf{y}=\mathbf{Y}-\overline{\mathbf{Y}}$ & $\mathbf{x y}$ & $\mathbf{x}^{\mathbf{2}}$ & $\mathbf{y}^{\mathbf{2}}$ \\
\hline Very Satisfied & 5 & 63 & 2 & -27.40 & -54.80 & 4 & 750.76 \\
\hline Somewhat Satisfied & 4 & 201 & 1 & 110.60 & 110.60 & 1 & $12,232.36$ \\
\hline Neither Satisfied nor Dissatisfied & 3 & 112 & 00 & 21.60 & 00 & 00 & 466.56 \\
\hline Somewhat Dissatisfied & 2 & 31 & -1 & -59.40 & 59.40 & 1 & $3,528.36$ \\
\hline Very Dissatisfied & 1 & 45 & -2 & -45.40 & 90.80 & 4 & 2061.16 \\
\hline Total $(\Sigma)$ & 15 & 452 & 00 & 00 & 206 & 10 & 19039.20 \\
\hline
\end{tabular}

Source: Authors' computation, 2019.

Hypothesis 2 states thus:

H02: There is no relationship between effective management of Credits to customers and Profitability in the banking industry in Nigeria.

Mean of Weighted Answer Options $\bar{X}=\frac{\sum X}{n}=\frac{15}{5}=3$

Mean of Frequency Response Options $\bar{Y}=\frac{\sum Y}{n}=\frac{452}{5}=90.40$

The Pearson's Product-Moment Correlation Co-efficient (PPMCC), ' $r$ ' is computed as follows:

From equation 2; PPMCC $r=\frac{\sum x y}{\sqrt{\sum x^{2} \sum y^{2}}}=\frac{206}{\sqrt{10 x 19039.20}}=\frac{206}{436.34}=0.4721$

Therefore:

The Pearson's Product-Moment Correlation Co-efficient (PPMCC) ' $r$ ' $=0.4721$ and

The Coefficient of Determination $(\mathrm{r} 2)=(0.4721) 2=0.2229$ or $22.29 \%$. 


\subsubsection{Testing Hypothesis 3 (H03)}

We derived the products for the computation of Pearson's Product-Moment Correlation Co-efficient (PPMCC) ' $r$ ' from Table 6.Hypothesis three (H03), states as follows.

H03: There is no relationship between effective management of Account Receivable and Payable and Profitability in the banking industry in Nigeria.

The Pearson's Product-Moment Correlation Co-efficient (PPMCC), ' $r$ ' is computed using the following process:

Mean of Weighted Answer Options: $\bar{X}=\frac{\sum X}{n}=\frac{15}{5}=3$

Mean of Frequency Response Options: $\bar{Y}=\frac{\sum Y}{n}=\frac{452}{5}=90.40$

Table 6. Computation of PPMCC, ' $r$ ' for RECEIVABLES AND PAYABLES AND PROFITability

\begin{tabular}{llllllll}
\hline & $\mathbf{X}$ & $\mathbf{Y}$ & $\mathbf{x}=\mathbf{X}-\ddot{\mathbf{X}}$ & $\mathbf{y}=\mathbf{Y}-\mathbf{\mathbf { Y }}$ & $\mathbf{x y}$ & $\mathbf{x}^{\mathbf{2}}$ & $\mathbf{y}^{\mathbf{2}}$ \\
\hline Very Satisfied & 5 & 117 & 2 & 26.60 & 53.20 & 4 & 707.56 \\
\hline Somewhat Satisfied & 4 & 242 & 1 & 151.60 & 151.60 & 1 & $22,982.56$ \\
\hline Neither Satisfied nor Dissatisfied & 3 & 40 & 00 & -50.40 & 00 & 00 & $2,540.16$ \\
\hline Somewhat Dissatified & 2 & 28 & -1 & -62.40 & 62.40 & 1 & $3,893.76$ \\
\hline Very Dissatisfied & 1 & 25 & -2 & -65.40 & 130.80 & 4 & $4,277.16$ \\
\hline Total $(\Sigma)$ & 15 & 452 & 00 & 00 & 398 & 10 & $34,401.20$ \\
\hline
\end{tabular}

Source: Authors' computation, 2019.

From equation 2; PPMCC $r=\frac{\sum x y}{\sqrt{\sum x^{2} \sum y^{2}}}=\frac{398}{\sqrt{10 x 34401.20}}=\frac{398}{586.53}=0.6786$.

Therefore:

The Pearson's Product-Moment Correlation Co-efficient (PPMCC) ' $r$ ' $=0.6786$ and

The Coefficient of Determination $(\mathrm{r} 2)=(0.6786) 2=0.4605$ or $46.05 \%$.

\section{Discussion of Findings, Conclusion and Recommendation}

\subsection{Discussion of Findings}

This study has three independent variables derived from the core areas of Working Capital Management (WCM). As earlier stated, they include: Short-term Investments, Credit to Customers and Account Receivables and payables. These independent variables were each tested against the dependent variable Profitability as per the hypotheses formulated. Data sourced were empirically analyzed using Pearson Product-Moment Correlation Coefficient (PPMCC) denoted by ' $r$ ' which attests to the degree and direction (positive or negative) of relationship between the variables. We also analyzed the data with the adjusted ' $r$ ' square referred to as the Coefficient of determination ( $\mathrm{r} 2$ ) which measures the proportion of variation of the dependent variable that is explained by the independent variables in the estimated model and it also gives some information about the goodness of fit of the model. The summary of result findings of the three hypotheses tested are displayed in Table 7

Table 7. Summary of results of the three null hypotheses tested

\section{$\operatorname{PPMCC}(\mathbf{r})$}

Coefficient of Determination (r2)

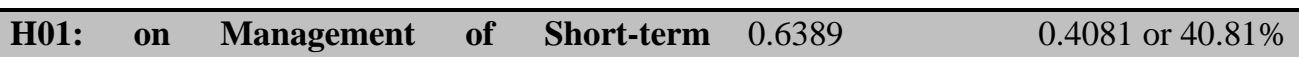




\begin{tabular}{lll}
\hline Investments and Profitability & & \\
\hline $\begin{array}{l}\text { H02: on Management of Credits to Customers } \\
\text { and Profitability }\end{array}$ & 0.4721 & 0.2229 or $22.29 \%$ \\
\hline $\begin{array}{l}\text { H03: on Management of Account Receivables } \\
\text { and Payable and Profitability }\end{array}$ & 0.6786 & 0.4605 or $46.05 \%$ \\
\hline
\end{tabular}

Source: Authors' computation, 2019

The table reveals that all the coefficients computed exhibit positive signs. This affirms that there is a positive relationship between Working Capital management (WCM) variables and Profitability in the banking industry in Nigeria. However, the strength of relationships as deduced from the magnitude of the coefficients is relatively on the average. They lack special distinction. Arranged in terms of size, the highest coefficient is 0.6786 - the coefficient, (PPMCC) ' $r$ ' between Account Receivable/Payable and Profitability. This is followed by that of Short-term Investments and Profitability whose coefficient (PPMCC) ' $r$ ' is 0.6389 and the lowest coefficient is 0.4721 ; the coefficient, (PPMCC) ' $r$ ' between Credit to customers and Profitability. Overall, these moderate coefficients that fall short of the magnitudes of coefficient expected appear to suggest that the WCM variables under review may not have been properly managed to yield sufficient cash flows that could generate very good profits. This must have been a lingering problem that defiled even the benefits of re-capitalization exercise of 2005 and all the mergers and acquisitions in the industry that occurred thereafter.

The results may partly explain why the banking industry has been faced with the problem of inadequate liquidity over the past decades. Up to the very recent time, the industry has been faced with distresses, outright liquidations, buyouts, mergers and acquisitions as a result of liquidity problems. In particular, the coefficient, (PPMCC) or ' $r$ ' between Credits to customers and Profitability stood very low at 0.4721 . Its relative Coefficient of determination was able to explain only $22.29 \%$ variation is Profitability. It clearly indicates inappropriate management of Credit to customers. Banking credits constitutes the largest proportion of total assets in the bank and is known to be the highest revenue earning asset in the industry. These results are leading us to infer that the somewhat deficiency in Credit management has been a core factor responsible for the liquidity problems in the banking industry in Nigeria. Evidently, banks in Nigeria were re-capitalized from N2 billion to N25 billion in 2005 but by 2009, the CEOs of five banks who were operating with negative shareholders' fund were dismissed as a result of toxic assets emanating from bad and doubtful debts. Consequent upon this, the Central Bank of Nigeria (CBN) embarked on a rescue operation mission to save ailing banks whose capital were eaten up by bad debts. This also led the apex bank to set up 'Asset Management Corporation of Nigeria (AMCON)' to buy up toxic assets (bad, doubtful and lost Credits) from banks to reposition them for acquisition by bigger banks. Recently, banks are still being bought over and acquired as a result of inadequacy in liquidity provisions. The Coefficient of Determination of the variables 'Short-term Investments' and 'Account Receivables and payables' stood low at $40.81 \%$ and $46.05 \%$ respectively. It implies that the variables only explained $40.81 \%$ and $46.05 \%$ respectively of variation in the dependent variable Profitability. Generally, these results cannot be said to be plausible and this calls for special attention from stakeholders in banking operations.

\subsection{Conclusion}

The study examined the imperative of effective Working Capital Management (WCM) and Profitability in the banking industry in Nigeria. We wish to reiterate that to enable detailed research and elaborate discussions on Working Capital management, it is broken into its components; that is, its fundamental areas which include: Managing Short-term Investments; Managing Credits to customers and Managing Account Receivable and Payables. The empirical analysis carried out was limited to these independent variables and the dependent variable Profitability in the banking industry in Nigeria. The empirical estimation was basically to determine the relationship between effective management of Short-term Investments, Credits to customers and Account Receivable and Payable and Profitability in the banking industry in Nigeria.

Based on the findings discussed above, we conclude that there is a positive relationship between Working Capital Management (WCM) and Profitability in the banking industry in Nigeria. The response frequencies showed distinct characteristics in the pie-charts and fundamentally, all the computed Pearson Product-moment Correlation Coefficient exhibited positive signs. However, the strength of relationship exhibited by the coefficients is somewhat on the average or relatively weaker than expected results. So, the results counter apriori expectation. We came to this conclusion because the results appear to suggest that WCM variables may not have been effectively managed since 
all empirically computed values of ' $r$ ' evidencing linear relationship lie on average levels. Besides, in all cases, the Working capital variables explained insignificant variation in the dependent variable - Profitability. By implication, it means that Profitability in the industry may not have been optimized and maximized since Working capital as indicated may not have been effectively managed.

Obviously, we have no doubts that the results will serve as contributory explanation to the persistent liquidity problems prevalent in the banking industry in Nigeria and will help stakeholders direct corrective actions appropriately to arrest the ugly tends in the industry. The results will also serve as contributory knowledge in this field of research and will provide ample opportunities for further researches in the future.

\subsection{Recommendations}

There is no doubt that to effectively manage Working capital requires professional skills. Certainly, it will also take the skill of the profession to manage Short-term investments, Credits to customers and Account Receivables and Payables. To arrest the problem of incompetence which is fundamental to this issue, we recommend the recruitment policy that emphasizes 'Competence by way of certification' into the industry. The industry as it is now appears to be made up of employees whose certificates are not in alignment to banking profession and that negate the ethics of the banking. On-the-job training and retraining is also recommended to be strictly enforced to compel ethical behaviours of the profession.

Secondly, Credits are volatile liquid funds that can easily be miss-appropriated by borrowers and miss-managed by creditors. The results though appear moderate, it calls for more efforts and serious attention to be paid to the management of Working capital components under review in order to enhance Profitability that would sustain adequate liquidity in the banking industry in Nigeria. We therefore recommend close surveillance of Credits by Directors of banks and Credit Officers with a view to reducing instances that could lead to bad debts and losses. This will not only enhance their profitability and liquidity positions but will also minimize the high level of toxic assets (bad debts) in the industry and as well maximize returns to shareholders in general.

Thirdly, to safeguard bank's cash and other liquid assets, Accounts Receivables and Payables processes should have strict internal controls measures to prevent vices such as paying a fraudulent invoice et cetera. Improper management of these account drains liquid funds which otherwise would have served as liquidity sources for higher profits.

Lastly, the need to maintain a viable portfolio of Short-term investments cannot be over-emphasized. These investments serve as liquidity buffers to help the bank meet up with sudden liquidity shocks and stay afloat. We therefore recommend that caution must be taken by Bank Management in the selection of assets that will constitute viable short-term investments.

\section{References}

Adegoke, O. (2017). Working Capital and Liquidity Position. The Nigerian Accountant, 40(3), 23-40.

Ahmed, F. (2015). The effect of working capital practices on risk management: Evidence from Jordan. Global Journal of Business Research, 5(1), 39-54.

Bandara, R. (2015). Impact of Working Capital Management Policy on Market Value Addition. Global Journal of Contemporary Research in Accounting, Auditing and Business Ethics (GJCRA), 1(2), 354-373.

Berryman, J. (2017). Small Business Failure and Bankruptcy: A survey of the Literature. European Small Business, 1(4), 47-59. https://doi.org/10.1177/026465608300100404

Chen, J. (2019). Liquidity Preference Theory. Retrieved from www.investopedia.com

Deloof, M. (2013). Does working capital management affect profitability of Belgian firms?. Journal of Business Finance and Accounting, (30), 573-588. https://doi.org/10.1111/1468-5957.00008

Hoque, A., Mia, A., \& Anwar, R. (2015). Working Capital Management andProfitability: A Study on Cement Industry in Bangladesh. Research Journal of Finance and Accounting, 6(7), 18-28.

Lovey, O. (2016). Effects of Micro Finance Banks Liquidity on the Working Capital of Small and Medium Scale Enterprises. International Journal of Business \& Law Research, 4(24), 53-59.

Mandiefe, S. P. (2016). How Working Capital Affects the Profitability of Deposit money banks: Case of Afriland Cameroon. Arabian Journal of Business and Management Review, 6(46), 1-9.

Maverick, J. (2019). What Is Working Capital Management? Retrieved from: https://www.investopedia.com/ask/answers/ 
Oaikhenan, H., \& Udegbunam R. (2004). Modern Statistics for Economics and Business. Benin City, H Henans Publishers in conjunction with URA Prints.

Ogodor, B., \& Mukolu, M. (2015). Working Capital Adequacy and Organization Performance. The Case Study of Banks in Nigeria. Journal of Research in Humanities and Social Science, 3(10), 20-25.

Oluboyede, A. (2017), Working capital and Liquidity Position. The Nigerian Accountant, 40(3).

Osisioma, B. (2017). Sources and management of working capital. Journal of Management Sciences, 2(3), 40-48.

Peel, M., \& Wilson, N. (2016). Working capita land financial management practices in the small firm sector. International Small Business Journal, 14(2), 52-68. https://doi.org/10.1177/0266242696142004

Rahaman, A., \& Nasr, M. (2017). Working capital management and profitability: Case of Pakistani firms. International Review of Business Research Papers, 3(1), 279-300.

Sabo, A. (2015). Illustration in Regression Analysis. International Journal of Forecasting, 8(4), 205-227.

Samiloglu, F., \& Demirgunes, K. (2008). The Effect of Working Capital Management on Firm Profitability: Evidence from Turkey. The International Journal of Applied Economics and Finance, 2, 44-50. https://doi.org/10.3923/ijaef.2008.44.50

Sayers, R. (1970). Modern Banking. Oxford, Oxford University Press.

Umoren, A., \& Udo, E. (2015). Working Capital Management and the Performance of Selected Deposit Money Banks in Nigeria. British Journal of Economics, Management, and Trade, 7(1). https://doi.org/10.9734/BJEMT/2015/15132

Wikipedia Encyclopedia. (2019). Working Capital: Wikipedia Encyclopedia. Retrieved from https://en.wikipedia.org/wiki/Working_capital

Wingaroja, G., \& O’Neil, S. (2018). A Study of Small Firm Exports, Policies and Support Institutions in Mauritius. Export and Industrial Development Division: Commonwealth Secretariat.

Yeboah, B., \& Yeboah, M. (2014). The Effect of Working Capital Management of Ghana Banks on Profitability: Panel Approach. International Journal of Business and Social Science, 5(10), 294-3. 